\title{
Responses of pelargonium (Pelargonium $\times$ hortorum L.H. Bailey) to long-term salinity stress induced by treatment with different $\mathrm{NaCl}$ doses
}

\author{
Włodzimierz Breś $^{1} \cdot$ Hanna Bandurska ${ }^{2}$ Agnieszka Kupska ${ }^{1} \cdot$ Justyna Niedziela $^{2}$ • \\ Barbara Frąszczak ${ }^{3}$
}

Received: 22 April 2015/Revised: 15 October 2015/Accepted: 10 December 2015/Published online: 28 December 2015

(C) The Author(s) 2015. This article is published with open access at Springerlink.com

\begin{abstract}
The aim of this research was to study the physiological and biochemical responses of pelargonium growing in saline substrate. Salt stress caused an increase of sodium and chlorine, and decrease potassium ions concentrations in pelargonium leaves depending on their level in peat substrate. About 4-16-fold increase of sodium, 4-6fold increase of chlorine were found in leaves of plants growing in substrate treated with the lowest (452 $\mathrm{mg} \mathrm{dm}^{-3}$ ) and highest $\left(2992 \mathrm{mg} \mathrm{dm}^{-3}\right.$ ) $\mathrm{NaCl}$ doses, respectively. The concentration of potassium ions decreased by 20 to $27 \%$ in leaves of plants growing in substrate supplemented with $\mathrm{NaCl}$ doses from 1976 to $2992 \mathrm{mg} \mathrm{dm}^{-3}$, respectively. However, lower doses of sodium chloride did not affect the content of potassium ions in pelargonium leaves. The increasing salinity of substrate after the addition of 960-2992 $\mathrm{mg} \mathrm{NaCl} \mathrm{dm}^{-3}$ caused the reduction of plant fresh matter in the range of 25-65\%, plant height $10-37 \%$, and leaf area $15-55 \%$. There were no changes in relative water content (RWC) and no signs of damage in the form of necrotic spots for any of the used salt concentrations. The content of chlorophyll pigments decreased proportionally to salt concentration, but the content of carotenoids did not
\end{abstract}

Communicated by N. A. Anjum.

Hanna Bandurska

bandur@up.poznan.pl

1 Department of Plant Nutrition, Poznań University of Life Sciences, Zgorzelecka 4, 60-198 Poznań, Poland

2 Department of Plant Physiology, Poznań University of Life Sciences, Wołyńska 35, 60-637 Poznań, Poland

3 Department of Vegetable Crops, Poznań University of Life Sciences, Dąbrowskiego 159, 60-594 Poznań, Poland change. Maximum photochemical activity of PSII $\left(F_{\mathrm{v}} / F_{\mathrm{m}}\right)$ was reduced only in plants growing at the highest dose of $\mathrm{NaCl}$. Proline and anthocyanin levels increased in response to elevated $\mathrm{NaCl}$ concentration. At the highest dose of $\mathrm{NaCl}$ proline level increased by $30 \%$ while the content of anthocyanins increased about 2.5 -fold in relation to the control. It can be assumed that proline and anthocyanins accumulated in pelargonium leaves may be responsible for the amelioration of the adverse effects of salt stress. The results revealed that the investigated pelargonium 'Survivor Dark Red' is somewhat tolerant to salinity and it can be cultivated in substrate and soil polluted with $\mathrm{NaCl}$ at the level lower than $1976 \mathrm{mg} \mathrm{dm}^{-3}$.

Keywords Pelargonium · Salinity · Chlorophyll fluorescence - Chloroplast pigments · Proline · Anthocyanins

\section{Introduction}

The term salinity implies high salt concentrations in soil or water. Salinity is a major environmental stress factor which limits plant growth and development, and its adverse effect is becoming a serious problem for more and more croplands as well as urban green belts (Türkan and Demiral 2009). In urban areas, the main cause of soil salinity is an excess of $\mathrm{NaCl}$ used to control black ice on roads and sidewalks which negatively affects the growth and appearance of many species of ornamental plants growing in green belts (Devecchi and Remotti 2004; Cunningham et al. 2008). Moreover, large amounts of salt may often be present in compost made from bio-waste which is used in the production of potting substrate for horticulture (Weinhold and Scharpf 1997). Thus, salinity is also a problem 
occurring in production and cultivation of ornamental plants used in landscaping. Salt-affected soil is becoming a serious problem in landscaping also because the shortage of high-quality water requires the re-use of wastewater for irrigation of green areas in the urban environment (Cassaniti et al. 2012). The genotypes of ornamental plants used in landscaping greatly differ in their susceptibility to salt stress (Villarino and Mattson 2011; Cassaniti et al. 2012). Some authors consider that pelargonium is characterized by high salt susceptibility (Kotuby-Amacher et al. 2000), but others classify this species as moderately salt susceptible (Miyamoto 2008).

High concentration of salt in the soil causes a decrease of soil water potential and osmotic stress which enable water uptake by plants (Cassaniti et al. 2012; Roy et al. 2014). The result of these disturbances in water management is a loss of turgor, inhibition of cell elongation, stomatal closure and a decrease in the intensity of photosynthesis (Munns and Tester 2008; Cassaniti et al. 2012). Moreover, salinity causes ionic stress that occurs due to the uptake and accumulation of ions $\left(\mathrm{Na}^{+}\right.$and $\left.\mathrm{Cl}^{-}\right)$in plant tissue, which has a deleterious effect on cell metabolism, enzymes activity and DNA (Mahajan and Tuteja 2005). Large amounts of ions that can be accumulated in chloroplasts may affect the degradation of chloroplast pigments and cause destabilization of protein complexes reducing the photosynthetic rate (Nandy et al. 2007; Jaleel et al. 2008; Tavakkoli et al. 2010). The disturbance of photosynthesis results in enhanced production of reactive oxygen species which cause oxidative stress and cell injury (Munns and Tester 2008; Carillo et al. 2011). A secondary effect of salt stress may be the disturbance in mineral nutrient uptake, leading to nutrient starvation (Munns and Tester 2008; Carillo et al. 2011). All these disorders result in the reduction of growth rate and limit plant development (Munns and Tester 2008; Moradi and Ismail 2007; Dkhil and Denden 2012).

Plants use various strategies to overcome the adverse effects of osmotic and ionic stresses caused by salinity (Munns and Tester 2008; Iqbal et al. 2014). The accumulation of protective compatible compounds such as proline has great significance in plant resistance to salinity (Ashraf and Harris 2004; Ashraf and Foolad 2007; Türkan and Demiral 2009; Surekha et al. 2014). In addition to its function as an osmolyte for intracellular osmotic adjustment, proline plays another crucial role because it acts as an enzyme protectant, free radical scavenger, cell redox balancer as well the stabilizer of subcellular structure (Ashraf and Foolad 2007; Hayat et al. 2012). There is also some evidence that salt stress induces accumulation of anthocyanins (Eryilmaz 2006; Dkhil and Denden 2012). This large group of water soluble pigments may play an important role in stress protection through minimizing oxidative damages (Wahid and Ghazanfar 2006). Moreover, the accumulation of these compounds in vacuoles may reduce leaf water potential, which prevents the loss of turgor (Hughes et al. 2010).

The scientific literature contains an extensive body of data concerning plant responses to high $\mathrm{NaCl}$ concentration in the root environment. Many previous experiments focused often on seedlings cultivated in water or sand cultures. Moreover, the dose of salt used in the experiments usually differs significantly from reality. Considerably fewer studies have been conducted on the effects of salinity on ornamental plants growing in saline soil or substrate, in the field or greenhouse conditions that are very close to the conditions of the production process. In view of the above, 2-year greenhouse experiments were carried out in order to assess the effect of increased concentration of $\mathrm{NaCl}$ in peat substrate on physiological and biochemical responses of pelargonium. The application rates of sodium were determined on the basis of earlier studies conducted in the city of Poznań (Poland). Depending on the traffic intensity and distance from the road pavement, urban soils contained 11-1010 mg Na dm ${ }^{-3}$ (Wilkaniec et al. 2012; Breś et al. 2014). So, the effect of low and high as well as intermediate salinity level, typical for urban soils, was tested. The effect of long-term salt stress on water content, $\mathrm{Na}^{+}, \mathrm{Cl}^{-}$ and $\mathrm{K}^{+}$ions concentration in leaves as well as on growth parameters, activity of photosynthetic apparatus and chloroplast pigment concentration has been assessed. The accumulation of anthocyanins and proline in leaves, as compounds that play an important role in mitigating salinity stress, was also evaluated.

\section{Materials and methods}

\section{Plant cultivation and treatment}

The experiments were conducted from 27 April 2012 to 14 July 2012 and from 26 April 2013 to 18 July 2013 in a greenhouse. Peat substrate at $\mathrm{pH}$ adjusted to 6.0 was used for plant cultivation. After liming the macro- and microcomponents the substrate was supplemented, providing the

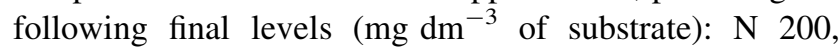
P 250, K 300, Fe 75, Mn 35, Zn 30, Cu 10, B 2 and Mo. Since it was established that the contents of $\mathrm{Ca}$ (1245 $\left.\mathrm{mg} \mathrm{dm}^{-3}\right)$ and $\mathrm{Mg}\left(160 \mathrm{mg} \mathrm{dm}^{-3}\right)$ were sufficient these components were not supplemented. Three rooted cuttings of Pelargonium $\times$ hortorum L.H. Bailey 'Survivor Dark Red' were planted into containers filled with $7 \mathrm{dm}^{3}$ of peat substrate to which different doses of $\mathrm{NaCl}$ were added. The following six doses of salt were used $\left(\mathrm{mg} \mathrm{dm}^{-3}\right.$ of substrate): 452, 960, 1468, 1976, 2484, 2992. Container with substrate to which no salt was added contained natural 
sodium $\left(22 \mathrm{mg} \mathrm{dm}^{-3}\right)$ and chloride $\left(13 \mathrm{mg} \mathrm{dm}^{-3}\right)$ constituted control combination. After applying $\mathrm{NaCl}$ the substrates contained 22 (control), 200, 400, 600, 800, 1000, $1200 \mathrm{mg} \mathrm{Na}$ and 13 (control), 287, 595, 903, 1211, 1519, $1827 \mathrm{mg} \mathrm{Cl} \mathrm{dm}^{-3}$ of substrate. The initial electrical conductivity (EC) of the substrates mixed with all components was as following: 0.11 (control), 0.62, 1.28, 1.75, 2.42, $2.82,3.72 \mathrm{mS} \mathrm{cm}^{-1}$. Each combination was composed of 10 containers with 3 plants. During plant cultivation additional fertilization with $\mathrm{N}\left(150 \mathrm{mg} \mathrm{dm}^{-3}\right), \quad \mathrm{P}$ $\left(80 \mathrm{mg} \mathrm{dm}^{-3}\right)$ and $\mathrm{K}\left(100 \mathrm{mg} \mathrm{dm}^{-3}\right)$ was applied in the middle of June to maintain the optimum conditions for pelargonium growth.

Substrate water content during experiments was kept at the level of about $60 \%$ of capillary water capacity. Water purified by reverse osmosis was used for plant watering (chemical composition of water is shown in Table 1). Therefore, the content of $\mathrm{Na}^{+}$and $\mathrm{Cl}^{-}$in the water did not affect the course of the experiment.

\section{Measurements of growth parameters}

Plant material for all analyzes was harvested from control and $\mathrm{NaCl}$ treated plants at the stage of full flowering (middle of July). Randomly chosen 20 plants from each treatment were used for the measurement of plant height and fresh mass of the aboveground part as well as the area of leaf blade. Leaf area was determined with the use of scanner and the SKWER software. For this purpose first leaf located above the second inflorescence was collected from 20 plants. The results are a mean from all measurements.

\section{Measurements of $\mathrm{Na}^{+}$and $\mathrm{K}^{+}$and $\mathrm{Cl}^{-}$ions}

Mineral content was determined in dried leaves. Fully mature leaves derived from nine randomly chosen plants were pre-dried at a temperature of $105^{\circ} \mathrm{C}$ for $48 \mathrm{~h}$ and grounded in a mixer. $\mathrm{Na}^{+}$and $\mathrm{K}^{+}$concentration by flame emission spectrophotometry was determined in plant material mineralized with a mixture of $\mathrm{H}_{2} \mathrm{SO}_{4}$ and $\mathrm{H}_{2} \mathrm{O}_{2}$ (2:1). For chlorine determination plant material was mineralized at a temperature of $500{ }^{\circ} \mathrm{C}$. Next the residue was dissolved in hot deionized water and after sedimentation the content of $\mathrm{Cl}^{-}$was determined in clear solution by the nephelometric method (Karla 1998). All analyses were carried out in three biological replicates. Each replicate derived from separate sample of plant material. Results of measurements are expressed as a percentage of dry matter (\%DM).

\section{Measurements of physiological and biochemical parameters}

Fully mature leaves (at similar developmental stage) taken from randomly chosen five plants were used for the estimation of water content as well as proline, chloroplast pigment and anthocyanin content. Tissue water content was estimated immediately after harvest. Plant material for estimation of other parameters was frozen in liquid nitrogen and stored at $-20^{\circ} \mathrm{C}$ until analyses. The analyses were carried out using five independent biological replicates. Each replicate derived from different samples of plant material.

\section{Water content in leaves}

Water content in leaves was estimated by measuring relative water content (RWC) according to the standard method developed by Weatherly (1950), and it was calculated using the following formula:

$$
\mathrm{RWC}=\frac{\text { fresh matter }- \text { dry matter }}{\text { fresh matter at full turgor }- \text { dry matter }} \times 100 .
$$

\section{Proline}

Proline content was measured according to Bates et al. (1973). Plant material (500 mg FW) was homogenized with $4 \mathrm{~cm}^{3}$ of $5 \%$ TCA. The homogenate was centrifuged at $5000 \mathrm{~g}$ for $15 \mathrm{~min}$. Supernatant was used for proline determination by measuring the quantity of the colored reaction product of proline with ninhydric acid. Absorbance was read at $520 \mathrm{~nm}$. The amount of proline in the sample was calculated from a standard curve and expressed in milligrams per gram of fresh matter $\left(\mathrm{mg} \mathrm{g}^{-1} \mathrm{FM}\right)$.

Table 1 Quality of water used for plant watering

\begin{tabular}{lllllllll}
\hline $\begin{array}{l}\mathrm{N}-\mathrm{NH}_{4} \\
\left(\mathrm{mg} \mathrm{dm}^{-3}\right)\end{array}$ & $\begin{array}{l}\mathrm{N}-\mathrm{NO}_{3} \\
\left(\mathrm{mg} \mathrm{dm}^{-3}\right)\end{array}$ & $\begin{array}{l}\mathrm{P} \\
\left(\mathrm{mg} \mathrm{dm}^{-3}\right)\end{array}$ & $\begin{array}{l}\mathrm{K} \\
\left(\mathrm{mg} \mathrm{dm}^{-3}\right)\end{array}$ & $\begin{array}{l}\mathrm{Ca} \\
\left(\mathrm{mg} \mathrm{dm}^{-3}\right)\end{array}$ & $\begin{array}{l}\mathrm{Mg} \\
\left(\mathrm{mg} \mathrm{dm}^{-3}\right)\end{array}$ & $\begin{array}{l}\mathrm{Na} \\
\left(\mathrm{mg} \mathrm{dm}^{-3}\right)\end{array}$ & $\begin{array}{l}\mathrm{S}-\mathrm{SO}_{4} \\
\left(\mathrm{mg} \mathrm{dm}^{-3}\right)\end{array}$ & $\begin{array}{l}\mathrm{Cl} \\
\left(\mathrm{mg} \mathrm{dm}^{-3}\right)\end{array}$ \\
\hline$<0.1$ & $<0.1$ & $<0.1$ & 0.1 & 2.6 & 0.1 & 0.8 & 0.1 & 0.2 \\
\hline $\mathrm{Fe}\left(\mathrm{mg} \mathrm{dm}^{-3}\right)$ & $\mathrm{Mn}\left(\mathrm{mg} \mathrm{dm}^{-3}\right)$ & $\mathrm{Zn}\left(\mathrm{mg} \mathrm{dm}^{-3}\right)$ & $\mathrm{Cu}\left(\mathrm{mg} \mathrm{dm}^{-3}\right)$ & $\mathrm{B}\left(\mathrm{mg} \mathrm{dm}^{-3}\right)$ & $\mathrm{HCO}_{3}^{-}\left(\mathrm{mval} \mathrm{dm}^{-3}\right)$ & $\mathrm{pH}^{\mathrm{EC}\left(\mathrm{mS} \mathrm{cm}^{-1}\right)}$ \\
\hline 0.028 & 0.006 & 0.061 & $<0.01$ & 0.004 & 0.43 & 7.12 & 0.039 \\
\hline
\end{tabular}




\section{Chloroplast pigments}

Total chlorophyll and carotenoids content was estimated according to the method of Hiscox and Israelstam (1979). Leaf samples $(100 \mathrm{mg})$ were cut into pieces and pigments were extracted at $65{ }^{\circ} \mathrm{C}$ using $5 \mathrm{~cm}^{3}$ of dimethyl sulfoxide (DMSO). Optical density of extract was measured at 480 , 649 and $663 \mathrm{~nm}$. The content of total chlorophyll and carotenoids was calculated following the modified Arnon equations (Wellburn 1994) and was expressed in milligrams per gram of fresh matter ( $\left.\mathrm{mg} \mathrm{g}^{-1} \mathrm{FM}\right)$.

\section{Anthocyanin pigments}

Content of anthocyanins was determined calorimetrically according to Wang et al. (2000). Plant material $(500 \mathrm{mg}$ ) was homogenized with $3 \mathrm{~cm}^{3}$ of $0.5 \mathrm{~N} \mathrm{HCl}$, and centrifuged at $6000 \mathrm{~g}$ for $10 \mathrm{~min}$. Absorbance of the supernatant was measured at $530 \mathrm{~nm}$. Anthocyanin content in leaf tissue was calculated using a calibration curve of cyanine chloride and was expressed in micrograms per gram of fresh matter $\left(\mu \mathrm{g} \mathrm{g}^{-1} \mathrm{FM}\right)$.

\section{Chlorophyll fluorescence}

Chlorophyll fluorescence parameters were measured to estimate the activity of the photosynthetic apparatus. The estimation was made on the fully expanded second or third leaf according to Maxwell and Johnson (2000) by means of a modulated fluorometer (Fluorometr OS1-FL, Optiscience). All measurements were made before noon after half an hour of plants adaptation to darkness and were performed in 24 replicates ( 2 leaves per plant from 12 randomly chosen plants per treatment). The dark adapter parameters were used to determine the maximum quantum yield of PSII (photosystem II) $\left[F_{\mathrm{v}} / F_{\mathrm{m}}=\left(F_{\mathrm{m}}-F_{0}\right) / F_{\mathrm{m}}\right.$ with $F_{0}=$ dark adapted initial minimum fluorescence, $F_{\mathrm{m}}=$ maximum fluorescence measured during the first saturation pulse after dark adaption]. The efficiency of excitation energy capture by open PSII reaction centers $\left(F_{\mathrm{v}}^{\prime} / F_{\mathrm{m}}^{\prime}\right)$ was calculated as: $F_{\mathrm{v}}^{\prime} / F_{\mathrm{m}}^{\prime}=\left(F_{\mathrm{m}}^{\prime}-F_{0}^{\prime}\right) / F_{\mathrm{m}}^{\prime}$

\section{Statistical treatment}

The results presented in figures and tables are the means from 2 years. All of the data were analyzed using STATISTICA 10 (StatSoft, Tulsa, OK, USA). Duncan's test was used to determine significant differences between the means. The level of significance was set at $\alpha=0.05$.

\section{Results}

It has been found that applied salt stress did not cause changes in water status of pelargonium leaves which shows that plants did not suffer from water deficit stress (Fig. 1). In contrast, the concentration of potassium, sodium and chlorine ions in leaves changed significantly with the increase of $\mathrm{NaCl}$ concentration in peat substrate, but in different pattern (Table 2). Salinity stress triggered statistically significant decrease of potassium ions concentration in leaves of pelargonium grown in substrate supplemented with three highest $\mathrm{NaCl}$ doses (1976, 2484 and $2992 \mathrm{mg} \mathrm{dm}^{-3}$ ). In relation to control combination the concentration of potassium ions decreased by about 20 and by about $27 \%$ in leaves of plants grown in substrate supplemented with 1976-2484 $\mathrm{mg}$ of $\mathrm{NaCl}$ and $2992 \mathrm{mg}$ of $\mathrm{NaCl}$, respectively.

On the contrary, the concentration of sodium and chlorine ions in pelargonium leaves was higher as the salinity in growing medium increased (Table 2). Sodium concentration in the leaves of control plants was at the level of $0.08 \%$ and was lower than the chlorine concentration $(0.32 \%)$. The concentration of both ions in leaves of pelargonium growing in peat substrate supplemented with the lowest $\mathrm{NaCl}$ dose $\left(452 \mathrm{mg}\right.$ of per $\left.1 \mathrm{dm}^{3}\right)$ increased about 3.8-fold. The progressive increase of $\mathrm{NaCl}$ concentration in peat substrate resulted in a further gradual increase of both ions concentration in pelargonium leaves. However, the concentration of sodium ions raised to a greater extent than chlorine ions. In leaves of pelargonium grown in substrate supplemented with the highest $\mathrm{NaCl}$

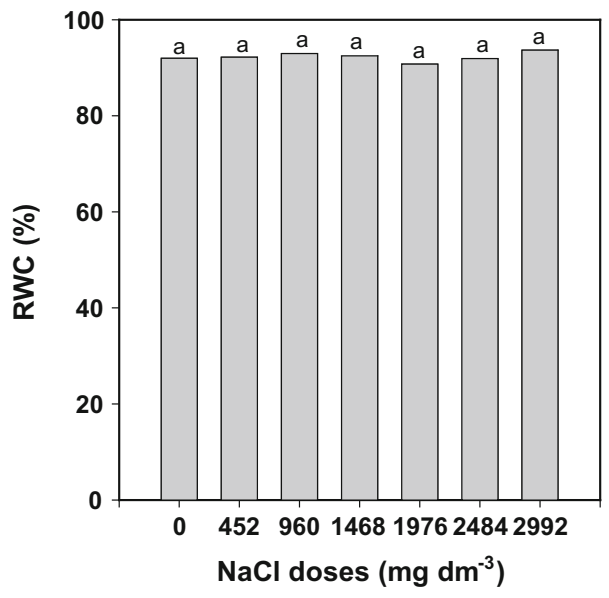

Fig. 1 Water content (RWC) in leaf blades of pelargonium grown in the peat substrate supplemented with various $\mathrm{NaCl}$ doses. Different letters indicate significant differences between means $(n=10)$ at $\alpha=0.05$ 
Table 2 Potassium, sodium and chlorine ions concentration $(\% \mathrm{DM})$ and $\mathrm{K} / \mathrm{Na}$ ratio in leaves of pelargonium grown in the peat substrate supplemented with various $\mathrm{NaCl}$ doses

\begin{tabular}{llllllll}
\hline Element & \multicolumn{2}{l}{$\mathrm{NaCl}\left(\mathrm{mg} \mathrm{dm}^{-3}\right.$ of substrate $)$} \\
\cline { 2 - 7 } & 0 & 452 & 960 & 1468 & 1976 & 2484 & 2992 \\
\hline $\mathrm{K}$ & $4.60 \mathrm{~cd}$ & $4.50 \mathrm{~cd}$ & $4.50 \mathrm{~cd}$ & $4.40 \mathrm{c}$ & $3.70 \mathrm{~b}$ & $3.63 \mathrm{~b}$ & $3.35 \mathrm{a}$ \\
$\mathrm{Na}$ & $0.08 \mathrm{a}$ & $0.31 \mathrm{~b}$ & $0.60 \mathrm{c}$ & $0.70 \mathrm{c}$ & $0.97 \mathrm{~d}$ & $1.23 \mathrm{e}$ & $1.34 \mathrm{e}$ \\
$\mathrm{Cl}$ & $0.32 \mathrm{a}$ & $1.23 \mathrm{~b}$ & $1.53 \mathrm{c}$ & $1.56 \mathrm{c}$ & $1.59 \mathrm{c}$ & $1.65 \mathrm{c}$ & $1.85 \mathrm{~d}$ \\
$\mathrm{~K} / \mathrm{Na}$ ratio & $57.50 \mathrm{c}$ & $14.51 \mathrm{~b}$ & $7.50 \mathrm{a}$ & $6.29 \mathrm{a}$ & $3.81 \mathrm{a}$ & $2.95 \mathrm{a}$ & $2.50 \mathrm{a}$ \\
\hline
\end{tabular}

Different letters indicate significant differences between means $(n=6)$ at $\alpha=0.05$
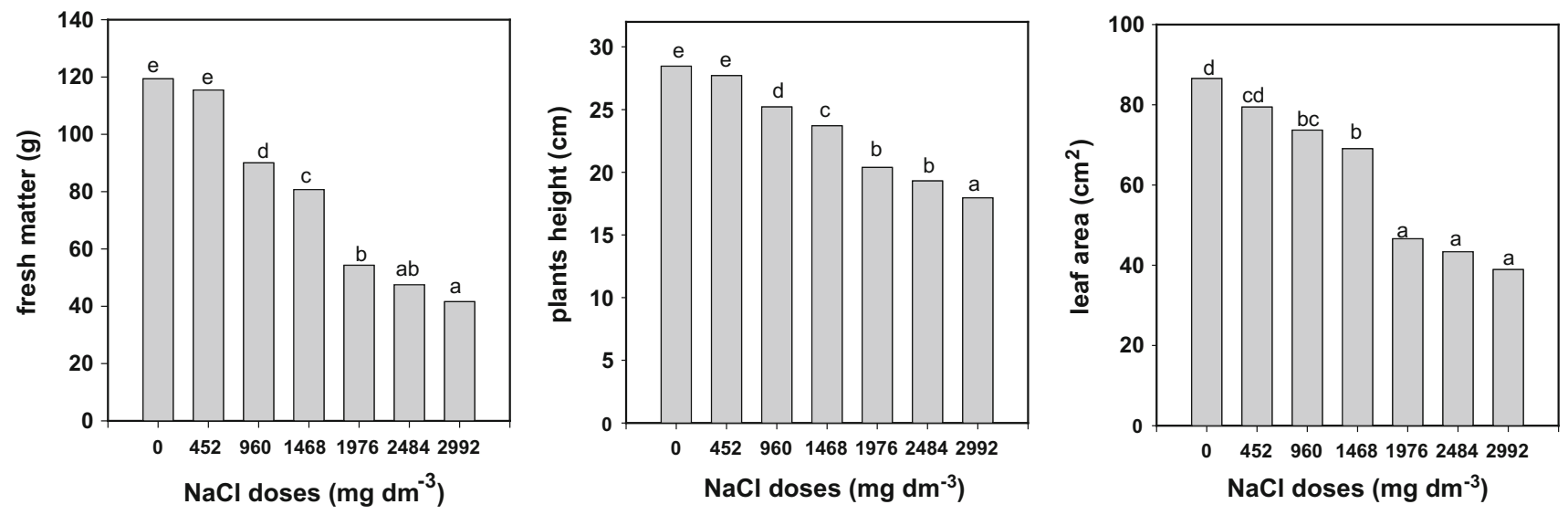

Fig. 2 Growth parameters (fresh matter, plant height, leaf area) of pelargonium grown in the peat substrate supplemented with various NaCl doses. Different letters indicate significant differences between means $(n=10)$ at $\alpha=0.05$

dose $\left(2992 \mathrm{mg}\right.$ of per $\left.1 \mathrm{dm}^{3}\right)$ the concentration of sodium increased about 16 -fold but chlorine only about 6 -fold. It is also worth noting that even though significant accumulation of these toxic ions there were no signs of damages in the form of necrotic spots for any of the used salt concentrations. As result of the decrease of potassium ions concentration and increase of sodium ions concentration in leaves the decrease of $\mathrm{K} / \mathrm{Na}$ ratio was observed with the growth of substrate salinity (Table 2).

The obtained results demonstrate that the increase of $\mathrm{NaCl}$ concentration in peat substrate had a negative effect on growth parameters (Fig. 2). After 2-3 weeks of growth in saline substrate plants clearly differed in size in comparison to those growing in non-saline substrate. At the end of the experiment a substantial reduction in fresh matter, height of plants and leaf area was found in pelargonium grown in substrate treated with doses of $\mathrm{NaCl}$ ranging from 960 to $2992 \mathrm{mg} \mathrm{dm}^{-3}$. These increasing $\mathrm{NaCl}$ doses caused progressive decrease of all growth parameters-the reduction of plant fresh matter ranged between 25 and $65 \%$, the height of the plants was reduced by $10-37 \%$ and leaf area by $15-56 \%$ in relation to the control. The highest growth inhibition was observed in plants having the lowest $\mathrm{K}^{+}$and highest $\mathrm{Na}^{+}$and $\mathrm{Cl}^{-}$ions concentration in leaves (Table 2; Fig. 2). As presented in Fig. 3 potassium ions concentration in leaves was positively correlated with fresh matter accumulation and leaf area. Whereas, sodium and chlorine ions concentration was negatively correlated with these growth parameters.

Salinity stress affected differently the content of chloroplast pigments in pelargonium leaves (Fig. 4). A significant decrease in the content of chlorophyll $a+b$ was observed in leaves of plants growing in peat substrate supplemented with doses of $\mathrm{NaCl}$ ranging from 960 to $2992 \mathrm{mg} \mathrm{dm}^{-3}$. The level of chlorophyll pigments in leaves of these plants was lower by 15-22\% compared to the control. Otherwise, the applied $\mathrm{NaCl}$ doses did not cause changes in the content of carotenoids in pelargonium leaves.

Changes in free proline and anthocyanins content in leaves of pelargonium growing in peat substrate containing increasing $\mathrm{NaCl}$ doses are presented in Fig. 5. Both proline and anthocyanins contents increased significantly in leaves of plants growing in peat substrate with the addition of two highest doses of $\mathrm{NaCl}\left(2484-2992 \mathrm{mg} \mathrm{dm}^{-3}\right.$ of substrate). The increase of these metabolites at both $\mathrm{NaCl}$ doses was similar as compared to control combination. However, it is worth mentioning that the level of proline increased only by $30 \%$ but anthocyanins content increased about 2.5 -fold in relation to the control. 
Fig. 3 The linear regression between concentration of potassium, sodium and chlorine ions in leaves and growth parameters (fresh matter, leaf area). All $r$ coefficients are significant at $p=0.05$
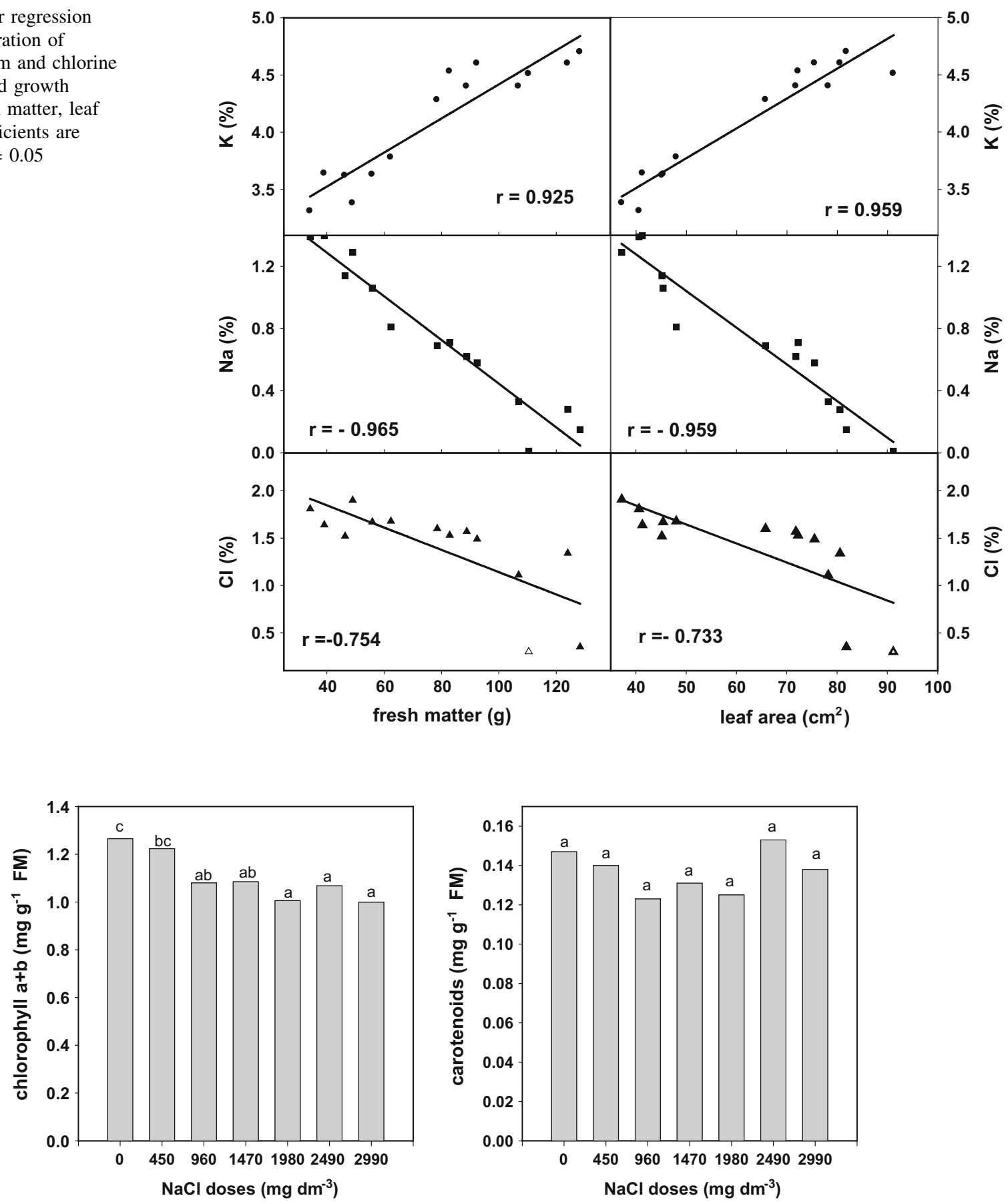

Fig. 4 Chloroplast pigments content in leaves of pelargonium pelargonium grown in the peat substrate supplemented with various $\mathrm{NaCl}$ doses. Different letters indicate significant differences between means $(n=10)$ at $\alpha=0.05$

The effect of increasing $\mathrm{NaCl}$ doses on chlorophyll fluorescence parameters are shown in Table 3. The ratio of $F_{\mathrm{v}} / F_{\mathrm{m}}$ changed from 0.830 in control plants to 0.822 in plants grown in substrate containing the highest salt dose. This reduction was statistically significant, which showed that the maximal photochemical activity (maximal quantum yield) of PSII was reduced only under conditions of the highest stress level. The efficiency of excitation capture by open PSII $\left(F_{\mathrm{v}}^{\prime} / F_{\mathrm{m}}^{\prime}\right)$ was increased in a pattern not dependable on sodium chloride dose. Indeed, a statistically significant increase was observed only in plants which were grown in peat substrate supplemented with 960 and $1976 \mathrm{mg}$ of $\mathrm{NaCl} \mathrm{dm}{ }^{-3}$. However, it should be noted that the described changes 

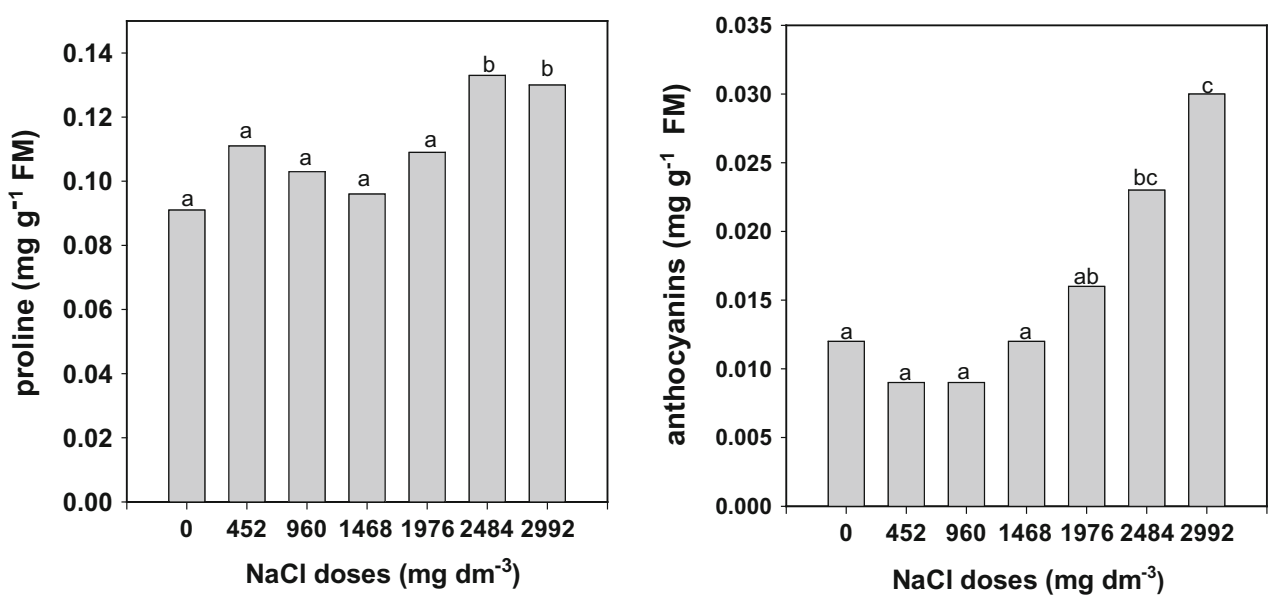

Fig. 5 Free proline and anthocyanins content in leaves of pelargonium grown in the peat substrate supplemented with various $\mathrm{NaCl}$ doses. Different letters indicate significant differences between means $(n=10)$ at $\alpha=0.05$

Table 3 Fluorescence parameters in leaves of pelargonium grown in the peat substrate supplemented with various $\mathrm{NaCl}$ doses

\begin{tabular}{lll}
\hline $\begin{array}{l}\mathrm{NaCl} \\
(\mathrm{mg} \mathrm{dm}\end{array}$ & $\begin{array}{l}\text { Maximum quantum } \\
\text { yield of PSII } \\
\left(F_{\mathrm{v}} / F_{\mathrm{m}}\right)\end{array}$ & $\begin{array}{l}\text { Efficiency of excitation energy } \\
\text { capture by open PSII reaction } \\
\text { centers PSII }\left(F_{\mathrm{v}}^{\prime} / F_{\mathrm{m}}^{\prime}\right)\end{array}$ \\
\hline 0 & $0.830 \mathrm{a}$ & $0.771 \mathrm{~b}$ \\
452 & $0.829 \mathrm{a}$ & $0.780 \mathrm{a}$ \\
960 & $0.837 \mathrm{a}$ & $0.774 \mathrm{~b}$ \\
1468 & $0.835 \mathrm{a}$ & $0.770 \mathrm{~b}$ \\
1976 & $0.830 \mathrm{a}$ & $0.780 \mathrm{a}$ \\
2484 & $0.837 \mathrm{a}$ & $0.773 \mathrm{ab}$ \\
2992 & $0.822 \mathrm{~b}$ & $0.771 \mathrm{~b}$
\end{tabular}

Different letters indicate significant differences between means $(n=24)$ at $\alpha=0.05$

in chlorophyll fluorescence parameters were rather small.

\section{Discussion}

The results obtained confirm the significant effect of salinity on the growth of pelargonium, which was manifested by a gradual decrease of fresh matter accumulation of the aerial parts as well as a reduction of leaf area with the increasing concentration of sodium and chlorine ions in peat substrate. This stress factor at least contributed to the reduction of plant height. Inhibition of leaf growth upon salt stress is among others caused by the osmotic effect of salt in soil which influences the reduction of water supply to leaf cells and a decrease in turgor pressure (Munns and Tester 2008). In the present study, we did not find a reduction in leaf RWC under the influence of any of the given $\mathrm{NaCl}$ doses, which indicates the absence of negative impact of salt stress on the hydration of cells. No differences in RWC among plants watered once a week with a solution containing from 0 to $2950 \mathrm{mg} \mathrm{NaCl} \mathrm{dm}^{-3}$ was also found in calla lily (Veatch-Blohm et al. 2012). The ability to maintain turgor in that plant probably resulted from the accumulation of $\mathrm{Na}^{+}$as well as $\mathrm{Ca}^{2+}$ and $\mathrm{Mg}^{2+}$ ions in leaves. In plants growing at high $\mathrm{NaCl}$ concentration, due to similarity between these ions, voltage-dependent $\mathrm{K}^{+}$channels appear to be one of the pathways for the entry of $\mathrm{Na}^{+}$ions to the root (Xiong and Zhu 2002; Tavakkoli et al. 2010). Transport of $\mathrm{Na}^{+}$and $\mathrm{Cl}^{-}$from the root to the aerial parts of plants and the accumulation in vacuoles can serve as a mean to lower water potential of cells and maintain balance (osmotic adjustment) between plant cells and low extracellular osmotic potential caused by salt, which may be responsible for turgor maintenance (Gaxiola et al. 2001; Xiong and Zhu 2002; Verslues et al. 2006). In addition, the sequestration of these ions in the vacuole is considered an important mechanism of salinity tolerance (Roy et al. 2014). The results presented here revealed a several-fold increase of $\mathrm{Na}^{+}$and $\mathrm{Cl}^{-}$ions concentration in leaves of pelargonium growing in saline substrate. Bearing in mind that the decrease in the concentration of $\mathrm{K}^{+}$ions was much smaller it can be assumed that turgor maintenance in leaves of salt-stressed pelargonium may be caused by the accumulation of $\mathrm{Na}^{+}$and $\mathrm{Cl}^{-}$ ions.

The results presented here show that visible reduction of leaf area in pelargonium was not caused by the decrease of RWC. Likewise, growth inhibition and no changes in turgor potential were also observed in leaves of long term salt stressed maize (Cramer and Bowman 1991). Some authors have shown that growth restriction in leaves and roots of plants exposed to long and short term moderate salinity and drought stresses was caused by the decrease in cell wall 
extensibility (Neumann 1993; Chazen and Neumann 1994; Schultz and Matthews 1993). So, the lack of relationships between salt stress induced reduction in leaf area and RWC revealed in our study shows that growth inhibition could be associated with the decrease of cell wall extensibility. Such changes in cell wall properties may have been a main reason of growth restriction in pelargonium exposed to $\mathrm{NaCl}$ doses, which inhibited growth without affecting PSII system. This may also indirectly indicate that $\mathrm{Na}^{+}$and $\mathrm{Cl}^{-}$ ions are mainly accumulated in the vacuole. However, from the correlation of $\mathrm{Na}^{+}$and $\mathrm{Cl}^{-}$concentration in leaves with leaf area and fresh matter accumulation the negative impact of these ions on plant growth was revealed. So, the accumulation of $\mathrm{Na}^{+}$and $\mathrm{Cl}^{-}$could also take place in cytoplasm and adversely affect cell metabolism. Growth reduction could be caused by the toxic effect of $\mathrm{Na}^{+}$and $\mathrm{Cl}^{-}$ions which comprises disruption of stomatal regulation, chlorophyll degradation, reduction in the photosynthetic rate and other processes responsible for growth (Ashraf and Harris 2004; Mahajan and Tuteja 2005; Munns and Tester 2008; Tavakkoli et al. 2010; Cassaniti et al. 2012). Growth reduction in saline irrigated calla lilies was caused by the inhibition of photosynthesis through the decrease of chloroplast pigments content and stomatal conductance as well as changes in chloroplast structure (Veatch-Blohm et al. 2012). A gradual decrease in total chlorophyll content was revealed in leaves of tomato, red cabbage, potato, cucumber, cotton and barley exposed to increasing salt concentration (Stępień and Kłobus 2006; Eryilmaz 2006; Jamil et al. 2007; Meloni et al. 2003; Tavakkoli et al. 2011). A significant decrease of chlorophyll level in leaves of pelargonium was noted in plants growing in substrate supplemented with three highest $\mathrm{NaCl}$ doses which had the greatest negative impact on growth. The decrease of chlorophyll content may lead to the destruction of chloroplast structure, causing instability of pigment protein complexes and damage of the PSII antenna system (Singh and Dubey 1995; Stępień and Kłobus 2006). A considerable decrease in the efficiency of PSII $\left(F_{\mathrm{v}} / F_{\mathrm{m}}\right)$ accompanied by a decrease in chlorophyll content was observed in leaves of cucumber, radish and potato exposed to high $\mathrm{NaCl}$ doses (Stępień and Kłobus 2006; Jamil et al. 2007; Gururani et al. 2013). The results presented here demonstrate a slight decrease in maximum quantum yield of PSII in plants grown at the highest salt dose, which, however, was lower than in the experiment cited above. Furthermore, salinity did not trigger the decrease in efficiency of energy excitation capture by open PSII $\left(F_{\mathrm{v}}^{\prime} / F_{\mathrm{m}}^{\prime}\right)$. Similar results were obtained in radish, where salt concentration-dependent reduction in the level of chlorophyll and maximum quantum yield of PSII, and no changes in efficiency of excitation capture by open PSII were shown
(Jamil et al. 2007). No negative effect of salt stress on maximum quantum yield of PSII and efficiency of excitation capture by open PSII in the halophytic plant Suaeda salsa is considered an important strategy to grow in very high saline soil (Lu et al. 2002). On the other hand, the significant decrease in photochemical efficiency of PSII took place in salinized rice somaclonal lines which are highly susceptible to salinity (Rachoski et al. 2015). Moreover, long term salt stress caused higher decrease of chlorophyll fluoresce parameters in salt-sensitive than salttolerant wheat cultivar which was also characterized by a greater content of glycinebetaine protecting photosystem complex against the harmful effect of stress (Khan et al. 2012). In our opinion, a slight effect of salinity on maximum quantum yield of PSII and the lack of negative effect on the efficiency of excitation capture by open PSII in pelargonium leaves could be caused by the fact that the measurements were performed after 10 weeks of plant growth in saline substrate. During this period some adaptation of plants to those adverse stress conditions may have taken place. Positive impact on the protection of photosynthetic apparatus, especially at higher salinity levels could be caused by the accumulation of anthocyanins and proline, leading to osmotic adjustment (Chalker-Scott 1999; Carillo et al. 2011; Hayat et al. 2012). Moreover, both proline and anthocyanins may protect plant cells from salt stress induced oxidative damage (Winkel-Shirley 2002; Banu et al. 2009; Verslues and Sharma 2010; Hayat et al. 2012). In addition to alleviation of salt stress induced oxidative damages, anthocyanins could bind to the toxic ions and protect cytoplasmic structures and chloroplasts from their adverse effects on photosynthesis (Wahid and Ghazanfar 2006). An increase of anthocyanins levels was observed in leaves of Bellis perennis as well as in cotyledons and hypocotyl of tomato and red cabbage seedlings treated with various concentrations of $\mathrm{NaCl}$ (Eryilmaz 2006; Khavari-Nejad et al. 2008). A salt tolerant sugarcane clone was characterized by a threefold higher anthocyanins level than a sensitive one (Wahid and Ghazanfar 2006). It may be speculated that significant anthocyanins accumulation in leaves of pelargonium grown in substrate supplemented with high $\mathrm{NaCl}$ doses, little effect of this stress on maximum quantum yield of PSII, and no effect on the decrease of efficiency of energy excitation capture by open PSII indicate their participation in protection of the photosynthetic apparatus.

The beneficial role of proline in plant responses to salt stress has been observed in many experiments with transgenic plants having increased level of proline as well as in the study performed with exogenous proline application (Xiong and Zhu 2002; Mahajan and Tuteja 2005). Mutant of Medicago truncatula that cannot synthesize proline 
showed higher sensitivity to salinity which was evidenced by decreased seedling growth and chlorophyll content (Nguyen et al. 2013). Moreover, higher proline concentration was found in more salt-tolerant than salt-sensitive species (Ashraf and Harris 2004). The genotypes of Brassica spp. showed a smaller decline in yield under salinity stress, accumulated a significantly higher proline level and were able to maintain higher RWC and membrane stability index (Chakraborty et al. 2012). In the present study, we found no reduction in the level of RWC even in plants growing at high doses of salt in peat substrate, and the increased level of proline which may indicate its participation in osmotic adjustment. Proline accumulated under stress conditions may also act directly as a scavenger of reactive oxygen species as well as an inducer in gene expression of several antioxidative enzymes, and as a protectant of PSII (Yazici et al. 2007; Hossain and Fujita 2010; Szabados and Savouré 2010; De Carvalho et al. 2013; Filippou et al. 2014). The results obtained in the present study may indicate participation of proline in the protection of the photosynthetic apparatus, which is evidenced by the increased level of this amino acid, slight reduction in maximal quantum yield of PSII and lack of reduction in the efficiency of excitation capture by open PSII in leaves of pelargonium growing at high salt concentration. The positive role of proline in alleviation of cadmium induced reduction of chlorophyll fluorescence parameters was shown in wheat (Iqbal et al. 2015). Moreover, proline accumulation during osmopriming of rape seeds improved post-priming germination and seedlings performance under salt stress which was seen in the increase of chlorophyll fluorescence parameters (Kubala et al. 2015).

In conclusion, this study supports the hypothesis that both antocyanins and proline may play a beneficial role in the tolerance of examined 'Survivor Dark Red' pelargonium to salt stress. These compounds may function as osmotic adjusters as well as scavengers of oxygen radicals protecting cytoplasmic structures and chloroplasts from adverse effects of toxic ions. In spite of the decrease in growth parameters no decrease in leaf water content, or signs of injury such as leaf browning and necrosis as well as a substantial decrease in maximal efficiency of PSII were observed. Salt concentration at which a $50 \%$ reduction of fresh matter was observed is considered a threshold salinity level for a particular plant (Shannon and Grieve 1999; Wallender and Tanji 2012). Based on growth response to salinity our data indicate that pelargonium may be considered a plant moderately tolerant to salinity. Three highest salinity levels (1976, 2484, $2992 \mathrm{mg} \mathrm{NaCl} \mathrm{dm}^{-3}$ ) triggered the reduction of fresh matter from 50 to $65 \%$. The obtained results show that examined pelargonium cultivar can be recommended for cultivation in substrate and soil polluted with moderate $\mathrm{NaCl}$ doses $(<1976 \mathrm{mg}$ $\mathrm{NaCl} \mathrm{dm}{ }^{-3}$ ).

Author contribution statement WB-experimental design, planning and conducting experiments, participation in preparing manuscript; $\mathrm{HB}$ - data analysis, discussion of results and preparation of manuscript; $\mathrm{AK}$ - conducting experiments, statistical analysis; $\mathrm{JN}$-measurement of RWC, proline, chlorophyll and anthocyanins; BF-measurement of fluorescence parameters, data analysis.

Open Access This article is distributed under the terms of the Creative Commons Attribution 4.0 International License (http://crea tivecommons.org/licenses/by/4.0/), which permits unrestricted use, distribution, and reproduction in any medium, provided you give appropriate credit to the original author(s) and the source, provide a link to the Creative Commons license, and indicate if changes were made.

\section{References}

Ashraf M, Foolad MR (2007) Roles of glycine betaine and proline in improving plant abiotic stress resistance. Env Exp Bot 59:206-216

Ashraf M, Harris PJC (2004) Potential biochemical indicators of salinity tolerance in plants. Plant Sci 166:1-3

Banu NA, Hoque A, Watanabe-Sugimoto M, Matsouka K, Nakamura Y, Shimoishi Y, Murata Y (2009) Proline and glycinebetaine induce antioxidant defense gene expression and suppress cell death in cultured tobacco cells under salt stress. J Plant Physiol 166:146-156

Bates LS, Waldren RP, Teare JD (1973) Rapid determination of proline for water stress studies. Plant Soil 39:205-207

Breś W, Kozłowska A, Kupska A (2014) The salinity of soils located along the selected streets of Poznan. Current trends in the horticultural plants cultivation. In: National scientific conference, Lublin-Susiec, 12-13 June 2014, p 40 (in Polish)

Carillo P, Annunziata MG, Pontecorvo G, Fuggi A, Woodrow P (2011) Salinity stress and salt tolerance. In: Shanker AK, Venkateswarlu B (eds) Abiotic stress in plants-mechanisms and adaptations. InTech, Croatia, pp 21-38

Cassaniti C, Romano D, Flowers TJ (2012) The response of ornamental plants to saline irrigation water. In: Garcia-Garizabal I (ed) Irrigation-water management, pollution and alternative strategies. InTech, Croatia, pp 131-139

Chakraborty K, Sairam RK, Bhattacharya RC (2012) Salinity-induced expression of pyrrolline-5-carboxylate synthetase determine salinity tolerance in Brassica spp. Acta Physiol Plant 34:1935-1941

Chalker-Scott L (1999) Environmental significance of anthocyanin in plant stress responses. Photochem Photobiol 70:1-17

Chazen O, Neumann PM (1994) Hydraulic signals from the roots and rapid cell wall hardening in growing maize leaves, are primary responses to PEG induced water deficit. Plant Physiol 104:1385-1392

Cramer GR, Bowman DC (1991) Kinetics of maize leaf elongation 1. Indirect yield threshold limit short term steady stead elongation rates after exposure to salinity. J Exp Bot 42:1417-1426

Cunningham MA, Snyder E, Yonkin D, Ross M, Elsen T (2008) Accumulation of deicing salts in soils in urban environment. Urban Ecosyst 11:17-31 
De Carvalho K, De Campo MKF, Domingues DS, Pereira LFP, Vieira LGE (2013) The accumulation of endogenous proline induces changes in gene expression of several antioxidant enzymes in leaves of transgenic Swingle citrumelo. Mol Biol Rep 40:3269-3279

Devecchi M, Remotti D (2004) Effect of salts on ornamental ground covers for green urban areas. Acta Hortic 643:153-156

Dkhil BB, Denden M (2012) Effect of salt stress on growth, anthocyanins, membrane permeability and chlorophyll fluorescence of okra (Abelmoschus esculentus L.) seedlings. Am J Plant Physiol 7:174-183

Eryilmaz F (2006) The relationships between salt stress and anthocyanin content in higher plants. Biotechnol Biotechnol Eq 20:47-52

Filippou P, Bouchagier P, Skotti E, Fotopoulos V (2014) Proline and reactive oxygen/nitrogen species metabolism is involved in the tolerant response of the invasive plant species Ailanthus altissima to drought and salinity. Env Exp Bot 97:1-10

Gaxiola RA, Li J, Undurraga S, Dang LM, Allen GJ, Alper SL, Fink GR (2001) Drought- and salt-tolerant plants result from overexpression of the AVP1 $\mathrm{H}^{+}$-pump. Proc Natl Acad Sci USA 981:11444-11449

Gururani MA, Upadhaya ChP, Strasser RJ, Yu JW, Park SW (2013) Evaluation of abiotic stress tolerance in transgenic potato plants with reduced expression of PII manganese stabilizing protein. Plant Sci 198:7-16

Hayat S, Hayat Q, Alymeni MN, Wani AS, Pichtel J, Ahmed A (2012) Role of proline under changing environments. Plant Signal Behav 7:1-11

Hiscox JC, Israelstam GF (1979) A method for the extraction of chlorophyll from tissue without maceration. Can J Bot 57:1332-1334

Hossain MA, Fujita M (2010) Evidence for a role of exogenous glycinebetaine and proline in antioxidant defense and methylglyoxal detoxification systems in mung bean seedlings under salt stress. Physiol Mol Biol Plant 16:19-29

Hughes NM, Reinhardt K, Field TS, Gerardi AR, Smith WK (2010) Association between winter anthocyanin production and drought stress in angiosperm evergreen species. J Exp Bot 61:1699-1709

Iqbal N, Umar S, Khan NA, Iqbal M, Khan R (2014) A new perspective of phytohormones in salinity tolerance: regulation of proline metabolism. Env Exp Bot 100:34-42

Iqbal N, Khan R, Nazir F, Asgher M, Per TS, Khan NA (2015) Selenium and sulfur influence ethylene formation and alleviate cadmium-induced oxidative stress by improving proline and glutathione production in wheat. J Plant Physiol 173:9-18

Jaleel CA, Sankar B, Sridharan R, Panneerselvam R (2008) Soil salinity alters growth, chlorophyll content and secondary metabolite accumulation in Catharanthus roseus. Turk J Biol 32:79-83

Jamil M, Rehman S, Lee KJ, Kim JM, Kim HS, Rhae S (2007) Salinity reduced growth PS2 photochemistry and chlorophyll content in radish. Scientia Agricola 64:1111-1118

Karla YP (1998) Handbook of reference methods for plant analysis. CRC Press, Taylor \& Francis Group, Boca Raton, p 287

Khan MIR, Iqbal N, Masood A, Khan NA (2012) Variation in salt tolerance of wheat cultivars: role of glycinebetaine and ethylene. Pedosphere 22:746-754

Khavari-Nejad RA, Bujar M, Attaran E (2008) Evaluation of anthocyanin contents under salinity $(\mathrm{NaCl})$ stress in Bellis perennis L. In: Khan MA, Weber DJ (eds) Ecophysiology of high salinity tolerant plants. Springer, pp 124-134

Kotuby-Amacher J, Koenig R, Kitchen B (2000) Salinity and plant tolerance. Electronic publishing. All Archived Publications. Paper 43.http://digitalcommons.usu.edu/extension_histall/43
Kubala S, Wojtyla Ł, Quinet M, Lechowska K, Lutts S, Garnczarska M (2015) Enhanced expression of proline synthesis gene P5CSA in relation to seed osmopriming improvement of Brassica napus germination under salinity stress. J Plant Physiol 183:1-12

Lu C, Qiu N, Lu Q, Wang B, Kuang T (2002) Does salt stress lead to increased susceptibility of photosystem II to photoinhibition and changes in photosynthetic pigment composition in halophyte Suaeda salsa grown outdoors? Plant Sci 163:1063-1068

Mahajan S, Tuteja N (2005) Cold, salinity and drought stresses: an overview. Archiv Biochem Biophys 444:139-158

Maxwell K, Johnson GN (2000) Chlorophyll fluorescence: a practical guide. J Exp Bot 51:659-668

Meloni DA, Oliva MA, Martinez CA, Cambria J (2003) Photosynthesis and activity of superoxide dismutase, peroxidase and glutathione reductase in cotton under salt stress. Env Exp Bot 49:69-76

Miyamoto S (2008) Salt Tolerance of landscape plants common to the southwest. Texas A\&M Univ Sys TR 316:1-37

Moradi F, Ismail AM (2007) Responses of photosynthesis, chlorophyll fluorescence and ROS-scavenging systems to salt stress during seedling and reproductive stages in rice. Ann Bot 99:1161-1173

Munns R, Tester M (2008) Mechanisms of salinity tolerance. Annu Rev Plant Biol 59:651-681

Nandy P, Das S, Ghose M, Spooner-Hart R (2007) Effects of salinity on photosynthesis, leaf anatomy, ion accumulation and photosynthetic nitrogen use efficiency in five Indian mangroves. Wetlands Ecol Manag 15:347-357

Neumann PM (1993) Rapid and reversible modification of extension capacity of cell walls in elongating maize leaf tissue responding to root addition and removal of $\mathrm{NaCl}$. Plant Cell Env 16:1107-1114

Nguyen ML, Kim G-B, Hyun S-H, Lee S-Y, Lee Ah-Y, Choi H-K, Choi H-K, Nam Y-W (2013) Physiological and metabolomic analysis of a knockout mutant suggests a critical role of MtP5CS gene in osmotic stress tolerance of Medicago truncatula. Euphytica 193:101-120

Rachoski M, Gazquez A, Calzadilla P, Bezus R, Rodriguez A, Ruiz O, Menendez A, Santiago M (2015) Chlorophyll fluorescence and lipid peroxidation changes in rice somaclonal lines subjected to salt stress. Acta Physiol Plant 37:117. doi:10.1007/s11738015-1865-0

Roy SJ, Negrão S, Tester M (2014) Salt resistant crop plants. Curr Op Biotech 26:115-124

Schultz HR, Matthews MA (1993) Growth, osmotic adjustment, and cell wall mechanics of expanding grape leaves during water deficits. Crop Sci 33:287-294

Shannon MC, Grieve CM (1999) Tolerance of vegetable crops to salinity. Sci Hortic 78:5-38

Singh AK, Dubey RS (1995) Changes in chlorophyll $a$ and $b$ contents and activities of photosystems 1 and 2 in rice seedlings induced by $\mathrm{NaCl}$. Photosynthetica 31:489-499

Stępień P, Kłobus G (2006) Water relations and photosynthesis in Cucumis sativus L. leaves under salt stress. Biol Plant 50:610-616

Surekha C, Kumari KN, Aruna LV, Suneetha G, Arundhati A, Kishor PK (2014) Expression of the Vigna aconitifolia P5CSF129A gene in transgenic pigeon pea enhances proline accumulation and salt tolerance. Plant Cell Tiss Org Cult 116:27-36

Szabados L, Savouré A (2010) Proline: multifunctional amino acid. Trends Plant Sci 15:89-97

Tavakkoli E, Rengasamy P, McDonald GK (2010) High concentration of $\mathrm{Na}^{+}$and $\mathrm{Cl}^{-}$ions in soil solution have simultaneous detrimental effects on growth of faba bean under salinity stress. J Exp Bot 61:4449-4459 
Tavakkoli E, Fatehi F, Coventry S, Rengasamy P, McDonald KG (2011) Additive effects of $\mathrm{Na}^{+}$and $\mathrm{Cl}^{-}$ions on barley growth under salinity stress. J Exp Bot 62:2189-2203

Türkan YI, Demiral T (2009) Recent developments in understanding salinity tolerance. Env Exp Bot 67:2-9

Veatch-Blohm ME, Malinowski M, Keefer D (2012) Leaf water status, osmotic adjustment and carbon assimilation in colored calla lilies in response to saline irrigation. Sci Hortic 144:65-73

Verslues PE, Sharma S (2010) Proline metabolism and its implications for plant-environment interaction. Arabidopsis Book 8:e0140. doi:10.1199/tab.0140

Verslues PE, Agarwal M, Katiyar-Agarwal S, Zhu J, Zhu J-K (2006) Methods and concepts in quantifying resistance to drought, salt and freezing, abiotic stresses that affect plant water status. Plant J 45:5235-5239

Villarino GH, Mattson NS (2011) Assessing tolerance to sodium chloride salinity in fourteen floriculture species. HortTechnol 21:539-545

Wahid A, Ghazanfar A (2006) Possible involvement of some secondary metabolites in salt tolerance of sugarcane. J Plant Physiol 163:723-730

Wallender WW, Tanji KT (2012) Agricultural salinity assessment and management, 2nd edn. American Society of Civil Engineers (eds), p 1094. doi:10.1061/9780784411698.fm

Wang H, Arakawa O, Motomura Y (2000) Influence of maturity and bagging on relationship between anthocyanin accumulation and phenylalanine ammonia-lyase (pal) activity in 'Jonathan' apples. Postharvest Biol Technol 19:123-128
Weatherly PE (1950) Studies in water relation of cotton plants. The measurement of water deficits in leaves. New Phytol 49:81-97

Weinhold F, Scharpf H-C (1997) Tolerance of ornamental plants to salt, sodium and chloride in potting substrates containing compost made of separately collected organic residues. Acta Hort 450:221-228

Wellburn AR (1994) The spectral determination of chlorophylls a and $\mathrm{b}$, as well as total carotenoids, using various solvents with spectrophotometers of different resolution. J Plant Physiol 144:307-313

Wilkaniec B, Breś W, Frużyńska-Jóźwiak D, Borowiak-Sobkowiak B, Wilkaniec A (2012) The assessment of chemical properties of soil, the chemical composition of leaves and the occurrence of diseases on Acer platanoides and Tilia cordata in selected sites of urban greenery in Poznań. Phytopathol 65:19-28

Winkel-Shirley B (2002) Biosynthesis of flavonoids and effects of stress. Curr Op Plant Biol 5:218-223

Xiong L, Zhu J-K (2002) Salt tolerance. Arabidopsis Book 1:e0048. doi:10.1199/tab.0048

Yazici I, Türkan I, Sekman AH, Demiral T (2007) Salinity tolerance of purslane (Portulaca oleracea L.) is achieved by enhanced antioxidative system, lower level of lipid peroxidation and proline accumulation. Env Exp Bot 61:49-57 